\section{The Women's Caucus for Political Science: A View of the "Founding"}

\author{
Joyce M. Mitchell, University of Oregon
}

action projects, particularly in cities, suburbs and around campuses.

\section{As a Subject for Political Science}

Why didn't American political science predict-or attach some significance to the signs of a movement of such pervasive dimensions? ${ }^{1}$

Shouldn't this be considered a critical sort of failure of American behav-

Science (WCPS) celebrates its 20th anniversary in the year '89-90. The organization was formed at the APSA meetings of September 1969 in New York, by younger women mostly. That year women also formally organized at the American Sociological and American Psychological meetings. The same followed in other professional and educational organizations.

This mobilizing came early in the 'second' women's movement. Socially aware women in the academic professions were literally waiting for this to come-'feminist' talk was a common informal theme whenever they got together. But there were all too few to do so at APSA meetings of the ' 60 s where a mere $5 \%$ were counted in the programs. First edition PS (Fall 1969, 668-69) photos of the meetings casually show many women; closer inspection tells more: APSA business was conducted entirely by males; very few women participated in the professional functions; they more often sat in audiences, provided service functions and were job seekers there.

These new groups were part of the much broader women's movement growing with considerable momentum at that time. Female students, flaunting counterculture styles, were also challenging traditonal feminine roles; the discontents of many housewives and 'middle American' women were roused by Friedan's The Feminine Mystique (1963) and similar messages. There were informal and 'consciousness-raising' groups, 'collectives,' and work, art and

\section{The received traditions of postwar political science offered little promise to women as aspiring professionals.}

ioral political science, with its scientific posture? For one thing, existing disciplinary definitions narrow the acceptable data for political study; political reality is framed by practitioners intent on some matters that preclude others. Value is placed on those recognized subjects and approaches. Nor did the predominant paradigms of the discipline fit this emergent casee. Group theory and pluralism focused on established groups as the major demand-makers, with economic interests primarily. Such power resources as status, position, economic leverage, skill and strategic access were less applicable to women. And in elite theory they were the non-decision-makers. Even less apt was the confusion of their intra-organization 'elite' positions with the powerful strata of society! Further, the subject of movements was relegated to sociology and history. Political system boundaries formally excluded most of this new activity.

Feminist theorists today point to more basic resistances. From the 'founding fathers' of classic political theory, to today's science and ideology, the framing of political phenomena has locked us into a single gender (cultural, racial) perspective (Brown 1988, Elshtain 1981, Nelson 1989, Pateman 1988, Sapiro 1983, Saxonhouse 1985). This critique has not been heard, or well understood, by the discipline. If political power rests on such differences, the stake in this noncomprehension can be formidable for the social sciences, and nowhere more so than in disciplinary selfreflection.

\section{Context: The Postwar Decades}

The received traditions of postwar political science offered little promise to women as aspiring professionals. Consider the $A P S R$, usually first encountered in graduate study. Finding recent women authors was almost impossible. In half the entire annual volumes of the two decades (up to '69) there were no female contributors of the main articles in this archive of 'professional contribution.' While women authors seemed to be coming forth during the war and right after (Overacker, Clark, Silva, Zeller, Weintraub, Kammerer), that short trend stopped in the ' 50 s, with a tide of male 'GI Bill' Ph.D.'s, European emigres and 'wartime specialists' re-establishing a male monopoly of contributions.

A couple of gender 'breaks' in the Review the prior decade demonstrate the point. Two women contributors appeared in classic political thought-hitherto not considered promising for women. Judith Shklar led the way in 1959, quite visible with the second article listed. Four more years passed before three more female contributions appeared, in the Civil Rights year of 1964: Shklar again and Hanna Pitkin with a contribution in two parts. But no trend of further contributors followed, although Pitkin did appear twice again. But the next five years were as 
scant in women contributors as before. In all, just 15 female writers $(1.5 \%)$ contributed major articles those prior two decades, yet somewhat over 1000 males did so!

\section{Change from Without}

In contrast, book publishers directly sought women's contributions, responding quickly to meet rising classroom and research demand. There were new subjects and approaches, comprehensive coverage, new 'definitive works,' catching scholarly and pedagogic interests. With flyers, displays and bookpersons pushing sales, professional attention multiplied and achievement mythology was enhanced. The book writer's product had both real and figurative 'turnover' for reputations and incomes at this time of rapid growth in the discipline.

Women authors were featured prominently. In the 60s Hannah Arendt, Gwendolyn Carter; Zeller, Shklar and Pitkin again; Dorothy Pickles, Kay Lawson and Doris Graber, received generous ad space for their books. And Marian Irish became a famous classroom name as 'Irish and Prothro' became a best seller text of the $60 \mathrm{~s}$, through many editions. Other women professionals achieved visibility as spousal coauthors who were given extensive ads: the Dimmocks, Sprouts and Mitchells, for example. Visibility, promise, and reputation extended beyond the confines of tradition, in this expanding and competitive arena.

In received tradition, the political science domain was thus a rarified male preserve, best symbolized by the long succession of male Presidents of the APSA (and 'white' too, as accentuated by the one exception, Ralph Bunche). It would take women to note the patriarchal caste of this, what the long roll of presidential names suggested to the 'outsider.'

\section{Rising Expectations}

With postwar higher education increasingly the path to careers, teaching and research opportunities expanded. With the flow of resource and program funds to education, the blend of individual and public goals grew thick. Democracy and equality, security and the Cold War, science and technology, economic growth and the U.S. role abroad-all spelled opportunity for many political scientists. From these also came new issues confronting political scientists, with repercussions for the discipline and the Association.

Enrollments in political science were increasingly rapidly in the $60 \mathrm{~s}$, as important issues were seen to be addressed by it, and students came flocking to tackle them. Aspirations to play leading roles, to 'be relevant' or make a committed contribution, distinguished the student of the $60 \mathrm{~s}$, from the more modest aims typifying the homecoming GI and career-until-

More than the forming of an organization, a revolution in rising expectations was occurring, following the classic profile. There would first be high hopes, then disappointment, and a seizing of the moment.

family coed of the 50 s.

The newer mentors (in contrast to the patriarchal fathers) came from broader social strata, thanks to the vets and to the greater numbers, especially at expanding public and urban campuses. They brought in place of formal 'distance,' more explicit commitment to the 'democratic creed,' including egalitarianism applied regardless of gender, race or cultural background. More than the high contributors of the profession, these classroom coaches would tell their students: "you have a mission; you can do it."2 Opportunity, ambition and hope were thus more widely inspired by the lay ministers, than by the high priests.

In this context, the actors of our drama take on more meaning and the arenas become obvious. More than the forming of an organization, a revolution in rising expectations was occurring, following the classic profile. There would first be high hopes, then disappointment, and a seizing of the moment. ${ }^{3}$

The immediate actors, our WCPS founders were distinguished from their collegial sisters going before by a major difference: most had just arrived at the point of embarkation on their careers. Most were in graduate work, while their senior collaborators held positions, but not as 'known' political scientists. The combined vantage points were extremely important; each necessary for the other to complete the cause. This enabled the roles and strategies played in the following events. The arenas were the annual APSA meetings, and more broadly, the regional association meetings too.

Recall as noted, the very few women with professional duties at these meetings, though with women functionaries, staff and spouses creating a mixed milieu. But then graduate students came in greater numbers to these events, as the market quickened. No longer a few deferential, proficient graduates striving for appropriate professional behavior. Groups and networks of grads looked for the 'big names,' the best panels, and the surrounding urban experience (by their standards). And women moved freely amongst them, no longer primarily as assiduous and dependent graduate assistants. New 'lifestyles' were also obvious, flouting traditional professional demeanor.

Thus there were 'two generations,' as Freeman (1975) points out for the women's movement as a whole. The contrast was marked; those holding positions had been through a recruitment process which weeded out most likely professional non-compliants. For sheer survival's sake there was a rigorous learning process in how to behave in order to be accepted as a woman professional (Mitchell and Starr 1971). The resulting role constraints were considerable, though mostly assumed as 'natural' by the community of male social scientists.

\section{Professional Discrimination}

Discrimination could flourish in relatively stable markets, and all traditions could be upheld more easily. Rapid market change aided the newcomers. In the prior decade almost $50 \%$ more new positions were added (BASS Report 1969), and 
rapidly expanding enrollments projected a need for new teachers which appeared well beyond the slower growth rates of $\mathrm{Ph} . \mathrm{D}$. production (Baker 1970, Lynn 1983). This created a 'luxury' market for new Ph.D. holders and ABD's, quite different from the older generation. The new women, in greater numbers, did not anticipate the segregation and constraints operating on those current women occupying solitary roles, mostly in institutions or positions of lower prestige (Mitchell \& Starr 1971).

\section{Consciousness: the First Stage of Solidarity}

Movement solidarity requires a leap in consciousness from one's own particular grievances to the commonality of the distress. This has special meaning for women whose social diffusion and political isolation have been particularly acute. Custom separated the women by family, marriage, formal and informal practice; and prevailing professional norms legitimized this (Cook 1987). An early feminist article labeled that moment of general recognition somewhere along the way, as a "click"a flash of recognition of very basic common circumstance. The "click" occurred for women in the Civil Rights movement when they recognized the rhetoric of rights to which they dedicated themselves did not extend to their own equal standing in the movement (Evans 1979). That click occurred in the formation of NOW (National Organization for Women) when accomplished women from state 'commissions on the status of women,' plus others, found they were being officially hushed when they sought an open call for women's rights (Freeman 1975).

At the 1969 APSA meetings in New York City, the critical moment came for political science women. Many had joined the New Caucus for Political Science (CNPS), especially younger aspiring professionals at larger, urban institutions. The CNPS had organized dissent 'from the left' initially, and focused concern on the discipline at the Annual Meetings, where they could all gather. Its initial successes, bringing a variety of professional issues into open debate, brought hope to women for action on their cause too.

\section{The Caucus for a New Political Science}

Initially organized in 1967 , the CNPS raised many issues: the Vietnam War, the involvement of professionals with covert intelligence, the diminished status of teaching, neglect of normative theory, formal disdain of applied research and strictures of professional neutrality on political issues. Problems of race received some attention in this crowded agenda, but the "women question" was hardly prominent. It was not included in the first program panels the CNPS organized for the 1968 meetings. ${ }^{4}$ Nor were women included effectively in its organiza-

\section{Protest action needs a theater, and many women were ready for that.}

tion. ${ }^{5}$ But it did challenge the APSA establishment on many concerns the women shared, while gaining prestigious support as it moved to contest elections. A further gesture came as one commission (of 10) was charged to look into the 'status of women in the profession' (swp)-the traditional phrase; no exhortatory language here. It was chaired by a concerned male! (PS Winter 1968, 38-40; Fall 1968, 17-18.)

\section{Official Response}

Political science women had also taken a prior initiative that engaged official response. Young women activists at the " 68 Washington meetings circulated a petition calling for an APSA study of the 'swp' (again). A barely legible copy shows a generous majority of the 82 signers were males. Simply signing a call for a 'swp' study could show liberal concern, but not necessarily an active feminist agenda. Indeed, the strength and activity of later WCPS members, regional and national, would show contrasting patterns from these signees. But the demand for some official attention was certainly expressed, and possibly with more effect, given the numerous male signers.

The APSA's response was prompt: a staff report to the Fall Council meeting from official records showed roughly comparable proportions of women's participation in APSA activities, to reported teaching positions-5\%. The minutes do not indicate, but surely some saw such a low percentage as shocking. An update of similar data for blacks was promised. All were referred to the Council's Executive Committee (PS Fall 1968, 27-28).

These were minor items, however, on the Council's agenda of 19681969. It was centrally and intently engaged with CNPS activity and demands: contesting APSA elections; constitutional reform; program panel participation by such nonofficial groups; APSA policies on professional ethics, free speech and positions on controversial subjects. The Council accepted some changes, to go then to the Annual Business Meeting, now highly attended and frought with the tension of confrontation. There the CNPS moved again, winning proscription on intelligence activity by APSA officers or staff (PS Winter 1969, 20-25). The officially proposed program sections also included more 'CNPS-sympathetic' subjects for the next year (words such as 'change, crisis, distress, violence, race, multi-ethnic' ...). But again nothing directly on women's issues (PS Winter 1969, 41; Spring 1969, 77-148).

In response to the petition, an APSA Committee on the Status of Women (APSA/CWSP) was created in Spring '69, and appointed approvingly by President Easton, along with another on the Status of Blacks (APSA/CSBP). The CSWP comprised just 5 members; the CSBP, 15, with 2 women (PS Spring 1969, 181-82). The small size of the women's committee (CSWP) proved a strategic asset, enabling cooptation of further members, noted below. But the committee appointment, merely listed among others in $P S$, focused little attention compared to action at the meetings, attended by the elite and newcomers, where discontents could be focused on 'the establishment.' Protest action needs a 
theater, and many women were ready for that.

\section{Frustration Leads to Founding}

The challenges of the CNPS disrupted ordinary professional decorum at the meetings and threatened to change a lot more. While disagreeable for some, the initial successes signaled promising change for others, thus adding momentum. The CNPS announced a scheduled public session on Women in Political Science for ' 69 in New York. This was described in $P S$ as "the first time in the history of the Association" on that subject (Spring 1969, 188).

That session provided the critical turning point. Various speakers made presentations-from the APSA's CSWP, the "Women's Liberation League" and NCPS advocates. The words are not remembered today, but somehow it became clear from it all that the CNPS welcomed the support of women, but their cause was not in its highest priorities. Once more that fateful "click!"

In small conversation groups afterwards, the women agreed they had to do something on their own. A group of five took on the practical business of creating an organization. They become an Executive Committee, CNPS fashion, with Katherine Klotzburger (Rutgers U.) as Chair; Audrey Wells (U. Fl.), Executive Secretary; plus Carol Barry (Syracuse U.); Berenice Carroll (U. IL), and Judith Stiehm (UCLA). Four were graduate students, one a very recent $\mathrm{Ph} . \mathrm{D}$. (Stiehm/Columbia U.) (PS Fall 1969: 678). They had the resources of professional aspirants: energy, hope, relative freedom from constraint, considerable organizational skills as urban university people, and with the CNPS as a caucus model. There was a definite 'Eastern nexus' among several, as in the core of the original CNPS. Indeed, CNPS Chair, Mark Roelofs, was a primary mentor of the WCPC Chair, Klotzburger, and other active women recall his encouragement.

Unlike the CNPS, however, the Women's Caucus organizers stressed a 'federal' structure, wherein regional and state units would have important roles too. This was a recognition that many more women participated in their local/regional chapters. Far fewer had their way paid to the national meetings, or could afford it. For professional women, APSA membership and activity at national meetings was the tip of an iceberg. Too many in those times were at the lower ranks, in part-time positions, hired temporarily, were graduate students or otherwise pursuing professional goals from very marginal positions. Their ostensible $5 \%$ share of professional activity was thus deceptive. Although merit was not the dividing criterion, the lack of numerous prominent or visible women created a perception of insufficiency on the part of male APSA participants and elites who might have been well informed otherwise.

\section{The women agreed they had to do something on their own.}

Of course, invisibility is always an important part of patterns which add up to 'institutionalized discrimination,' most difficult for mainstream males to understand given their relative advantage in such a system.

The regional WCPS structure included chairers for the South (Stetson, FL-Atl.), Northeast (Klotzburger), New England (Rothschild, Harvard), Midwest (Graber, U. IL), and West (Stiehm, then at UCLA). Graber and Stetson brought some further seniority and position. More importantly, the regional units enabled more widespread activity in bringing women's views forward. It provided direct linkage, with incentives and resources, for otherwise localized women to take an active part in professional activities. The WCPS also gained from the diversity. ${ }^{6}$

\section{Access and Overlapping Memberships}

Some senior women, actively supporting the Women's Caucus, were in APSA positions which provided access for the women's cause in decisionmaking arenas. Nominations to the Council, often viewed as a pattern of 'tokenism,' brought a succession of feminists at the right time. The first break from the traditional line was Jo Milburn (Simmons C., Boston), fortunately appointed first chair of the APSA/CSWP as well. She introduced the first women's resolutions (WCPS-inspired, and referred to the CSWP) to the Council, and stood up to the melange of dodges and maneuvers (with little vocal support) as the Council tried to get beyond this to 'more important business.'

Overlapping memberships of Women's Caucus members with the Council and the APSA/CSWP was increased the next two elective years, as Jewel Prestage (Southern U., LA) and Joyce Mitchell (U. OR) were added. Prestage, longtime member of the active APSA 'pre-collegiate' committee, was also involved with the developing programs for blacks in the profession. The common causes of blacks and further emergent minorities, with those of women, comprised a stronger bloc calling for recognition and opportunity. With the real threat of the New Caucus looming large, the claims of these groups could gain more, as they did not challenge the APSA establishment and programs nearly so much.

Women gained further access when Mitchell, as Council member, was appointed the Executive Committee by President Lane, bringing Women's Caucus and APSA/CSWP interests to bear on its central deliberations. The case was made for more responsive APSA services and facilities for women-a more explicit share of the Association's 'public goods' hitherto not framed in terms of women's needs (Olsen 1965). They did achieve convention facilities, program space, and child care; open job listings, an information and liaison person (Walter Beach, also Editor of $P S$ ). They lost as to official auspices and office (or file) space, also considered badly needed by this dispersed group.

In 1969 an editorial board was created for $P S$, recently set up as newsletter of the Association. Betty Glad (U. IL) was one of five to serve on it, providing another access point for the WCPS. 


\section{Role of the Committee on the Status of Women in the Profession}

The APSA/CSWP played a very strategic role brokering the demands of the Women's Caucus through official procedures fraught with likely pitfalls. With Milburn as Chair, original members were Marian Irish (American U.), Mitchell, Prestage, and Susanne Rudolph (U. Chicago). Here there appeared a 'Washington connection' of several, most likely from the Executive Director's suggestion of names. The Kirkpatricks (Evron, APSA/ExDir and Jeane, Georgetown U.), friends of Milburn (and of later CSWP member, Victoria Schuck (Mt. Holyoke), contributed a supportive milieu. With this came very useful lateral access to APSA headquarters 'where things were done.' This helped inspire the ambitious program of the CSWP: its announcements, inquiries, travels to campuses, surveys and writings.

Further moves enhanced the effectiveness of the Committee. With a small initial membership, it designated additional members, including sympathetic males, whose professional recognition could bring further support in quite different spheres: Warren Ilchman (UC-Berkeley), Peter Bachrach (Temple U.) and Philip Converse (U. MI)-and James Prothro (U. NC) also served as advisor. The first Women's Caucus Chair, Klotzburger, was brought in as a member, and it worked with additional women activists such as Irene Tinker (Wash. DC), and Ruth Hawkins (Fordham, NY). By these efforts the CSWP embraced a broad political and professional spectrum, including several key Women's Caucus activists, and dealt with Association members in several arenas and activities.

This Committee, aided by APSA staff, ambitiously surveyed women in the profession, first with a departmental census of male/female faculty and students. Schuck reported the findings in PS (Fall 1969, 642-53; Summer 1970, 357-61). Even with a $1 / 2$ return rate, it was clear the $5 \%$ women faculty were concentrated in the lower ranks, in smaller institutions, with least access to teaching or scholarly honors. The more prestigious, or productive of Ph.D.'s the department, the fewer women faculty. This first extensive survey revealed patterns of such uneven distribution of this markedly small minority in political science, as to raise serious questions. While phrased in gloved terms, 'letting the facts speak for themselves,' the reports reached all APSA members, including women demanding change.

The Women's Caucus was gaining numbers, from an initial 42 (11 were men) in late ' 69 , to 159 signed up 6 months later, and 254 ( $52 \mathrm{men}$ ) by that summer (Glad 1989) - with further rapid increase in the years to follow. With their activities at the meetings, and the combined APSA/ CSWP efforts, women achieved a

\section{The regional units enabled} more widespread activity

in bringing women's views forward.

sudden and remarkable visibility of their own making. They were also riding a wave of rebellion and reform, in which their demands appeared more palatable than those brought from the more 'radical' CNPS.

\section{Excitement, Anger, Surprise}

Try to picture the tension, concern, excitement felt by members, old and new, with the entirely unprecedented issues and demands raised by the CNPS. The Business Meetings were the first battle ground, and attendance swelled. Never before such a clash of opposing values, interests and style. The onslaught of resolutions, amendments and attacks on existing programs brought defensive moves: new committees to which hostile resolutions could be referred, the mail ballot so more traditional nonparticipants could vote on candidates and issues, and use of discretionary parliamentary tools for handling surprise and disruption.

The New Caucus' efforts had remarkable effect in 68-69, with resolutions won at Business Meet- ings, accommodation in the program, aided by continued pressure from outside political issues such as the Vietnam War. The Women's Caucus-and the Black Caucus-followed the protest style in part. But their goals and resources differed significantly, so that basic strategies were in great contrast. The women had no 'prominent' leaders, but high cohesion over their common goal and rapidly increasing numbers active in several arenas. They could work together in a way more difficult for the prominent 'stars' in leadership roles of the New Caucus as it aimed more directly at the APSA 'power structure,' but with highly contrasting disciplinary and political priorities.

Yet women, too, encountered key resistance from those in the APSA and professional elite, significantly amongst those entering, or about to attain, leading roles in the Association as it was. The women's challenge of existing arrangements and calls for new rules were resisted. Some articulated the charge that the women were lacking in professional experience and meritorious stature. The paths to the upper meritocracy of the Association were not to be so easily opened.

The women had to explain their cause in greater specifics, to counter the persistance of informally expressed biases ('They are not committed, haven't published, haven't earned their way, put scholarship second to family, have more trivial disciplinary concerns' ...). Further APSA/CSWP studies addressed these problems (Converse \& Converse 1971, Mitchell and Starr 1971). Those myths, perpetuated by the cycle of discrimination, would be demonstrably broken by many of these newcomers, though there were prominent male social scientists having difficulty recognizing that the potential was becoming visible.

The combined efforts of the Women's Caucus and the CSWP pressed an agenda for expanded opportunity and participation on several fronts: in graduate programs (recruitment, admissions, time and age requirements, awards and scholarships), in career placement and employment practices (public listings and register of women, abolition of 
anti-nepotism rules, regularized parttime positions) and in professional activities (in APSA committees, positions and programs; research support; advancement to administrative and executive positions). Most WCPS resolutions went through the APSA/CSWP Committee/Council process, but WCPS members came up with further initiatives at the Annual Business Meetings (for 'generous' facilities and child care provisions at the Meetings; and condemning discrimination outright, with publication of instances).

Thus there was considerable scope and many specific targets for action, supported by surveys, studies and reported data. Above all there was persistent pressure in several important decision arenas. The APSA, especially its Executive Director and liaison for women, were urged to use a variety of implementation measures: publishing information on placement, program and research opportunities; liaison with other Washington-based associations for legal support and services (AAUP, AAUW and other social science associations); notification of political science departments as to resolutions and recommendations; cooperation with other social science associations on recruitment practices; and further search for research and program support from foundations and funding agencies (PS, Summer 1971, 462-67). Federal anti-discrimination and affirmative action policies added further encouragement at this time.

These initial successes against discrimination and for improved programs conveyed promise and considerable encouragement for the growing number of women in the profession. This was a high point of accomplishment and reward for active women who had joined the cause. All would not continue so easily: there would be a reaction of some new APSA officers; reversals in APSA nominations, elections, and appointments; severe reduction of the Committee's numbers and funds; a downturn in political science career prospects and APSA budgetary constraints, all of which could have meant the demise of the Women's Caucus if dependency were its reason for existence. But instead, its membership grew, it continued to recruit and support women in meaningful professional activity, and it brought new perspectives and challenges in the programs and projects it sponsored. The Women's Caucus for Political Science has proven it is here to stay, in good times and bad, with dedication and purpose. But that is another story to be told. Suffice it to say here, it met the times and circumstances of its founding with success, and with lasting impact on its profession.

\section{Notes}

My thanks to Kay Lawson for her helpful editorial suggestions.

1. Books by Duverger 1955, Gruberg 1968 , and Amundsen 1971, signaled a new subfield, but no resultant disciplinary refocus.

2. The Women's Caucus surveyed their mentors for this anniversary year, paying a most stirring tribute to those who uniquely cemented this intellectual and moral commitment. See Ricci (1984) on the role of the 'democratic creed,' in tension with the scientific persuasion.

3. My colleague, James C. Davis, also a cited mentor (above), specified the resultant

"J-curve"-frustrated expectations are critical.

4. The 1968 CNPS panels addressed prob-

lems of electoral choice; race, power, and money; the draft; mass media; liberal ideology; crime and corruption; Vietnam, radical political thought; and questions about America's capacity for "world leadership."

5 . The sole woman, of 13 , on the first CNPS ExCom, a graduate student, served as Secretary! The second year, 1968, brought 10 new leaders, many known male political scientists, but just one woman replacing the first-and again a graduate student. This time a male became "Recording Secretary."

6. Some examples from the West: Marie Rosenberg, 3d WCPS National President, sought a degree from the University of Washington only after a family and business. She broke early stereotypes about women's Caucus members, in a reputed altercation with APSA President Eulau, where she pointed out she was "a Republican, a grandmother, and the mother of your Dean" - at Stanford U.! Another Western recruit and 'late' Ph.D. (Minn. '68), Betty Nesvold, led the Western women, became WCPS President in 1978, was a longtime participant in APSA programs and positions, and was the Women's Caucus' first independent nominee for APSA President in 1980. The career paths of WCPS presidents and officers are themselves worthy of study. Many enjoyed impressive successes in professional positions.

\section{References}

Amundsen, Kirsten. 1971. The Silenced Majority. Englewood Cliffs, NJ: Prentice-
Hall.

Baker, Earl M. 1970. "A Survey of the Graduate Academic Marketplace in Political Science." PS Summer 1970, 366-73.

BASS Report. 1969. Heinz Eulau and James March, eds. Political Science (Behavioral and Social Sciences Survey). Englewood Cliffs: Prentice-Hall.

Brown, Wendy. 1988. Manhood and Politics; A Feminist Reading in Political Theory. Totowa, NJ: Rowman \& Littlefield.

Converse, Philip and Jean Converse. "The Status of Women as Students and Professionals in Political Science." PS, Summer, 1971, 328-348.

Cook, Beverly, 1987. "Support for Academic Women in Political Science 1890-1945." In The Politics of Professionalism, Opportunity, Employment and Gender, ed. Sarah Slavin. Binghamton, NY: Haworth.

Duverger, Maurice. 1955. The Political Role of Women. Paris: UNESCO.

Elshtain, Jean Bethke. 1981. Public Man, Private Woman. Princeton: Princeton University.

Evans, Sarah. 1980. Personal Politics: The Roots of Women's Liberation in the Civil Rights Movement \& the New Left. New York: Vintage Press.

Freeman, Jo. 1975. The Politics of Women's Liberation. New York: David McKay.

Glad, Betty. 1989. "Chronology: Important Developments of (the) Women's Caucus for Political Science 1969-79."' Presented at the APSA/Organized Section Panel (Women and Politics Research) on "Organizing Academically: The Experience of the Women's Caucus for Political Science."

Gruberg, Martin. 1968. Women in American Politics. Oshkosh, WI: Academia Press.

Lynn, Naomi B. 1983. "Self-Portrait: Profile of Political Scientists," in Political Science: State of the Discipline, ed. Ada W. Finifter. Washington, DC: American Political Science Association.

Mitchell, Joyce, and Rachel Starr. 1971. "Aspirations, Achievement and Professional Advancement in Political Science." In Women in Political Science. Washington, DC: APSA.

Nelson, Barbara J. 1989. "Women and Knowledge in Political Science: Texts, Histories and Epistemologies." Women and Politics 9(2): 1-25.

PS 1968-present. The American Political Science Association.

Pateman, Carole. 1988. The Sexual Contract. Stanford, CA: Stanford University.

Ricci, David M. 1984. The Tragedy of Political Science. New Haven: Yale.

Sapiro, Virginia. 1983. The Political Integration of Women. Urbana: University of Illinois Press.

Saxonhouse, Arlene W. 1985. Women in the History of Political Thought. New York: Praeger.

Schuck, Victoria. 1969. "Women in Political Science: Some Preliminary Observations." PS Fall, 1969, 642-53. 